\title{
On Paving Bricks on the Streets of the Southern Cities of the Song Dynasty
}

\author{
Hequn Li $^{\mathrm{a}}$; Zhiyi Song \\ College of civil engineering and architecture, Henan University, 475001, China \\ alihequn65@sina.com, rebeccade@yeah.net
}

\begin{abstract}
In the Song dynasty, brick-paved streets mainly emerged in the southern cities dealing with rainy weather and slippery road surface. This article discusses some brick-paved streets of the southern cities, such as Chengdu, Junzhou, Yangzhou, Hangzhou and Guangzhou. These streets were often slightly convex in the middle for the convenience of drainage. And there were always ditches at both sides and rammed earth beneath the paving bricks.
\end{abstract}

\section{Keywords-brick-paved streets; ditches; rammed earth}

\section{INTRODUCTION}

It is rainy all the year round in southern China, mainly the regions south of the Yangtze. So the urban streets are often muddy after rain. So in the Song Dynasty, the streets of the southern cities began to be paved with bricks (stone in few area), flanked with drainage ditches. This was a part of urban construction at that time, and has a certain reference value to today's municipal construction.

\section{THE BRICK-PAVED URBAN STREETS OF THE SONG DYNAST OF PRESENT-DAY SICHUAN PROVINCE}

There were many historical documents about paving urban streets of the Song Dynasty. For example, Chengdu city (belonging to Sichuan province today) of the Song Dynasty, its streets were made of earth. During rainy days they were very wet and slippery, and used to form many bumps and hollows on the roads after the rain, extremely difficult for traffic. In order to solve this issue, the government supplied some funds to employ the dwellers to pave the urban streets in 1177AD. These pavements consisted of bricks flanked with stone slabs. This program consumed over two million bricks and over twenty million Qian(the currency unit of ancient China). From then on, during rain people did not need wearing Qiao(a special kind of shoes worn in muddy road), were not afraid to slip down on the horse backs, and very easily walked whether fast or slow $^{[1]}$

Junzhou city of the Song Dynasty belongs to today's Sichuan province. These urban streets were also paved with bricks. According to the record by Yujing ${ }^{[2]}$, in $1037 \mathrm{AD}$ some Buddhists from the city raised one thousand Qian to employ workmen and to buy bricks and stones for paving these streets with ditches on both sides. This project took several years under the supervision of these Buddhists.

In recent years, one street site belonging to the Tang and Song periods was excavated in Chengdu city of Sichuan province. This site consisted mainly of street, some sites of houses and drainage facilities. This street was paved with special strip-shaped bricks in stagger joint work. The pavement was higher in the middle than both sides with one ditch on each side for draining ${ }^{[3]}$ (fig.1).

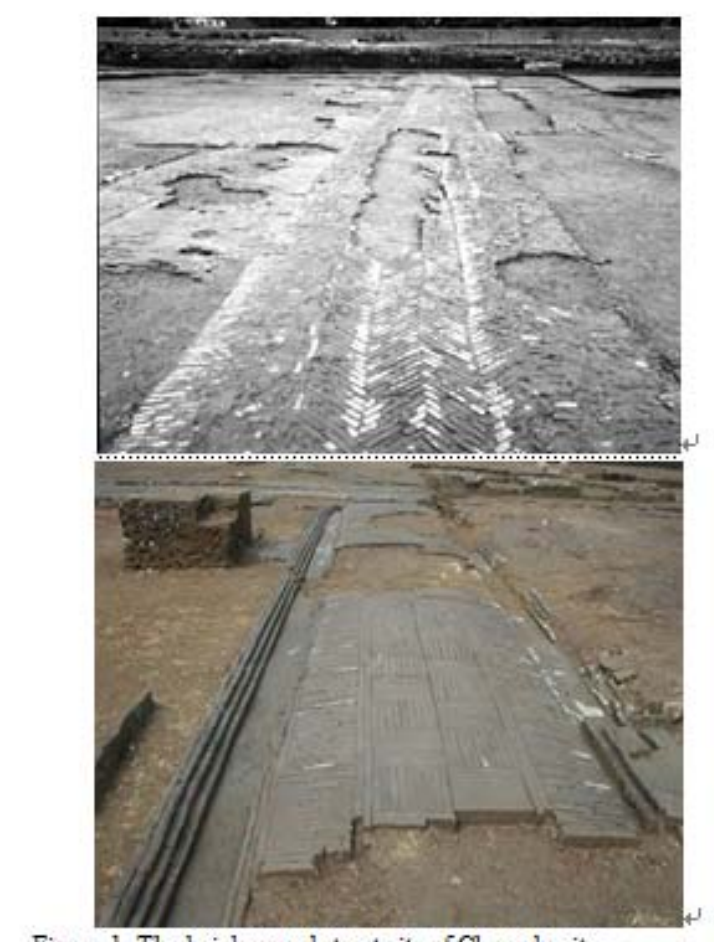

Figure.1. The brick-paved-street site of Chengducity -.

\section{THE BRICK-PAVED ROYAL STREET OF THE SOUTHERN SONG DYNASTY OF TODAY’S ZHEJIANG PROVINCE}

Present-day Hangzhou of Zhejiang province was the capital of the Southern Song Dynasty. On the Yan'guan street of Hangzhou, one royal street located at the north of the imperial palace was earthed. This brick-paved street could be divided into two parts named main lane and subsidiary one. Only one length of $10.2 \mathrm{~m}$ and one width of $7.2 \mathrm{~m}$ were uncovered. The central road surface slightly protrude up and tilted towards both sides in order to facilitate drainage. The main lane was built with long and narrow bricks called "Xianggao brick" with a size of $30 \times 8 \times 4 \mathrm{~cm}$. And these bricks were in the horizontal orientation. On the western side paved one longitudinal brick and horizontal brick measuring $37 \times 17 \times 7 \mathrm{~cm}$. One dividing line between the main lane and the western one was 0.45 meters wide. The western subsidiary lane measuring 5.15 meters in width was excavated and was longitudinally built with $30 \times 8 \times 4 \mathrm{~cm}$ bricks in stagger joint work. This lane was divided into three sections with a 
length of over 2 meters of each section between which there was a horizontal brick as one border. In addition, there was one ditch on each side of the street ${ }^{[4]}$ (fig.2).

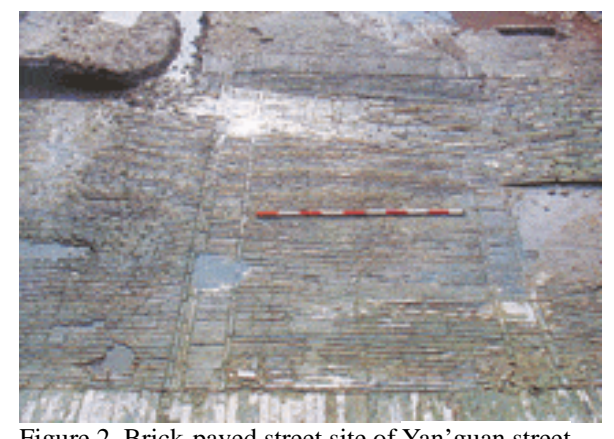

Figure 2. Brick-Daved street site of Yan'guan street

Another city where one brick-paved street was found is Ningbo, today's Zhejiang province. In the Zicheng site of Tang and Song Mingzhou city in present-day Ningbo city center, one brick-paved street of the Song Dynasty was found among which six meters were cleared. The street was $4.8 \mathrm{~m}$ wide and was paved with brick measuring $24-30 \times 7 \times 4 \mathrm{~cm}$ in stagger joint work. The street was first bedded with earth and rubble and tamped and then paved with bricks. There were stone slabs and open ditches flanked the street. The broken and worn bricks showed the street was frequently used. On the same layer, one section of street was found too. It was different from above street that its apron and open ditch were built in the center of the street. The bricks were tightly and tidily paved ${ }^{[5]}$ (fig.3).

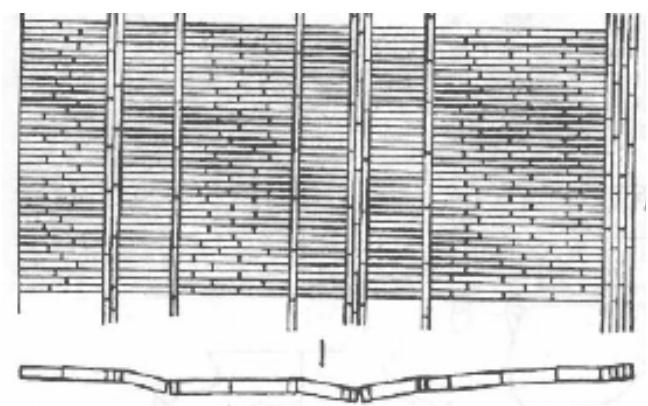

Figure 3. Brick-paved street site of Ningbo city

IV. THE BRICK-PAVED STREET CALLED “LUDAO” OF THE WESTERN GATE OF THE YANGZHOU GREAT CITY

According to a book about the Song period architecture, named "yingzhaofashi”,

"Ludao" was a kind of brick-paved street. The construction method was as follows: According to the specific circumstances decide the length and width, at the middle lay flat bricks flanked with two lines of vertical bricks ${ }^{[6]}$. There was an example about Ludao at the western gate of the Great City of Yangzhou city, today's Jiangsu province. Outside the western gate one brick-paved Ludao extended in the north-west direction, remaining one length of $31.93 \mathrm{~m}$ and one width of $3.5 \mathrm{~m}$. This road consisted of road surface, ditches and sidewalks. Excavation exposed the construction method. At first, rammed the road foundation with earth, burnt-soil, above which a layer of sand soil was paved. And then on the earth road surface, stone slabs measuring $3 \mathrm{~cm}$ width, $10 \mathrm{~cm}$ thickness, $50-80 \mathrm{~cm}$ length, were paved in the middle. From the stone slabs extended to both sides were brick-paved road surface, ditches and pavements. The brick road used wedge brick, paved in stagger joint work measuring $3.5 \mathrm{~m}$ in width, and was arch-shaped with a higher middle than two sides by about $10 \mathrm{~cm}$. The ditches of the both sides were $15 \mathrm{~cm}$ wide, about $10 \mathrm{~cm}^{\text {deep }}{ }^{[7]}$ (fig.4).

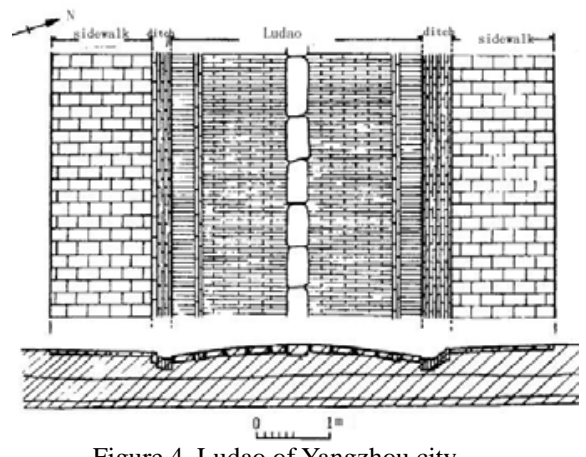

Figure 4. Ludao of Yangzhou city

\section{V.THE SONG-PERIOD BRICK-PAVED STREETS OF GUANGZHOU CITY, TODAY’S GUANGDONG PROVINCE}

Guangzhou city as the provincial capital was very prosperous in the Song dynasty, and its expansion and renovation were as many as over ten times. Beneath the Beijing road surface of this city several layers of ancient streets were cleared, including Han, Tang, Song and Ming dynasties. Among these, one Song dynasty street could be divided into four periods from bottom to top ${ }^{[8]}$. About the fourth period, or the top layer, its road surface was 1.25 1.35 meters deep from present-day street surface. It was shaped like slight arc, higher in the middle and lower on both sides flanked with stone stripes. The street was pave with some east-west bricks measuring $34-36 \mathrm{~cm}$ in length, $16-17 \mathrm{~cm}$ in width, $4.5-5.5 \mathrm{~cm}$ thickness (fig.5).

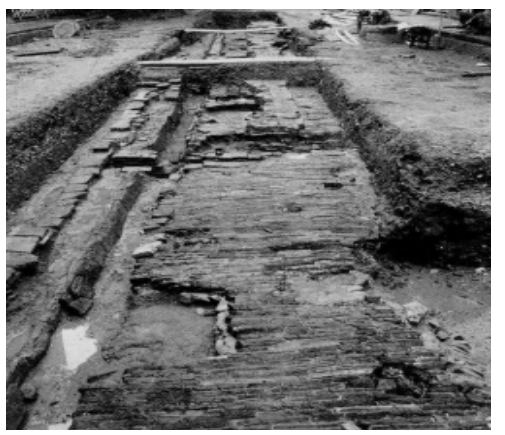

Figure 5. The fourth layer of the street site of Guangzhou city

The third period top was 1.41 meters deep from present-day street surface. The remaining road surface was level and paved with gray sandstone slabs with a size of $6-8 \times 35-40 \times 30-60 \mathrm{~cm}$. At the west side was a Stone block 
edge and beneath the road there was a one east-west drainage ditch. Beneath the slabs layer was rammed earth consisting of four layers 0.35 meters thick. The top layer was $8-10 \mathrm{~cm}$ thick and belonged to purer red clay in which a small number of ceramic chips were contained. The middle two layers, $10-12 \mathrm{~cm}$ thick, were yellow and red clay containing more brick fragments and ceramic chips. The bottom layer was sand having a lot of shells in it [9](fig.6).

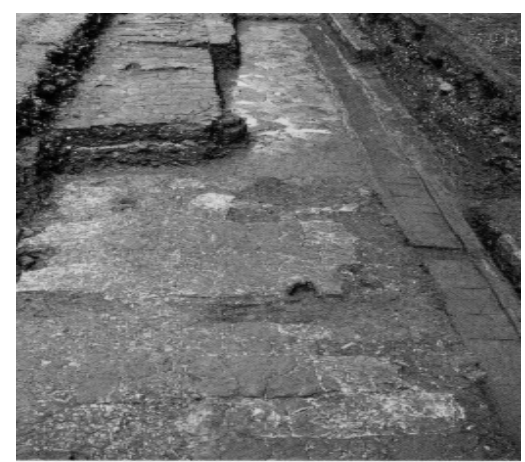

Figure 6. The third layer of the street site of Guangzhou city

The second layer was 1.75 meters deep from present-day street surface. The paving bricks in the middle were slightly higher than both sides flanked with ditches. The road consisted of the $\mathrm{v}$-shaped lines of bricks measuring $34 \times 16 \times 4 \mathrm{~cm}$.

The first layer, or the bottom one, was 2.15 meters from present-day street surface. The paving bricks were square ones measuring $42 \times 42 \times 5 \mathrm{~cm}$.

\section{SUMMARY}

In the Song dynasty, brick-paved streets mainly emerged in the southern cities to deal with rainy weather and slippery road surface. These streets were always convex in the middle for the convenience of drainage. There were ditches at both sides and rammed earth beneath the paving bricks. Of course, there were few stone-paved streets owning to using the local materials.

This article belongs to the Preliminary result of humanities and social science project of the Ministry of Education in China named "the research on the spatial distribution and its evolution of the Dongiing Kaifeng city of the Northern Song dynasty” (14YJA780001).

\section{REFERENCES}

[1] Qingbozazhi, Vol,2, Zhonghua publishing house,(1985,P41), Thread-Binding Books Publishing House,(2003,P1238).

[2] Yujing. the record of paving street of Junzhou, Chinese ancient architecture literature collection(Song, Liao, Jin and Yuan dynasties)(the Vol.1), Tongji University press,(2010,P73).

[3] Wangwei, Almanac of Chinese Archaeology (2009), Cultural Relics Publishing House, 2010, P389.

[4] Lishulei.Brief report on the excavation the royal street site on present-day Yanguan street of Hangzhou city, Hangzhou archaeology and museum, 2006(1).

[5] linshimin. The smaller city site of the Tang and Song period of Ningbo city, Zhezang province.Archaeology, 2002 (3).

[6] Lijie.Yingzaofashi,Vol.15, the people's publishing house,2006,P104.

[7] Yangzhou city archaeological team. excavations of the western gate of the great city, Song period Yangzhou. GREATCITY, SONGPERIODYANGZHOU)

[8][9] Guangzhou City Heritage Institute of Archaeology. The excavation of one-thousand-year-old ancient street on the Beijing road of Guangzhou city. Yangcheng archaeological discovery and research,Vol.1, Cultural Relics Publishing House,2005(p185);(P186). 